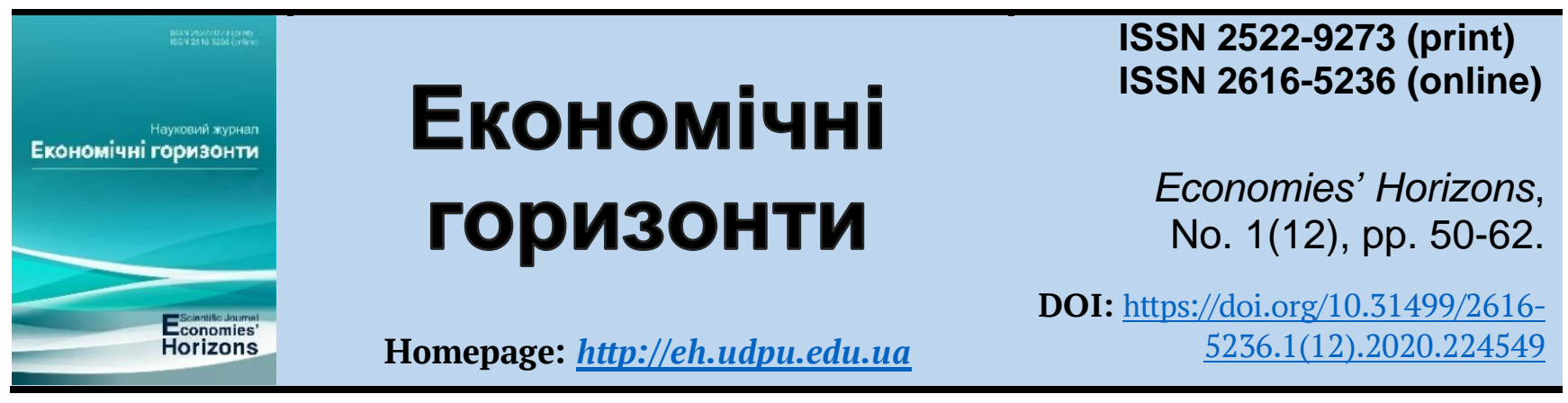

UDC 338.2[005.93:658.512.2

\title{
Strategic concept of national economy development in the focus of design management
}

Received: 11 February 2020

Accepted: 15 March 2020

\author{
Natalia O. Prokopenko ${ }^{1}$
}

Prokopenko, N. O. (2020), "Strategic concept of national economy development in the focus of design management”, Economies' Horizons, no. 1(12), pp. 50-62, doi: https://doi.org/10.31499/2616-5236.1(12).2020.224549
\end{abstract}

Abstract. The purpose of the article is to substantiate the strategic concept of national economy development in the focus of design management. Methodology. General scientific methods are used in the research, in particular theoretical generalization - to determine the theoretical foundations and trends of content and components of design management; system economic analysis - to substantiate the model of strategic economic transformations management in the context of design management; statistical analysis, namely correlation-regression analysis - to study the relationship between macroeconomic indicators and social indicators. Results. It is proved that the current economic model of the national economy is unsuitable for achieving the goals of sustainable development, ensuring the competitiveness of the state in the global environment and a decent standard of living in the long run. Attempts to improve (reform) certain parameters and components of the outdated model may lead to a loss of time and resources, which will cause Ukraine to further lag behind the developed countries of the world. Solving the problem of ensuring a decent living standard for citizens and the human potential development requires a comprehensive reengineering of the structure and processes of the socioeconomic system based on design management. Design management is an innovative concept of thinking. The study of its features allowed to formulate our own approach to determining the strategic management of the national economy. Under this approach, it is proposed to understand the process of designing a socio-economic model of development. The parameters of its operation will guarantee a decent satisfaction level of the population needs in the long run, the choice of a system of optimal strategies and mechanisms for their implementation, taking into account the factors of national security and environmental protection. The corresponding model of strategic management of economic transformations is substantiated. The main directions and priorities of economic policy (sectoral, fiscal, tariff, customs and public procurement policy) aimed at the implementation of qualitative structural transformations to ensure economic growth of the national economy in the strategic perspective are given. The correlation-regression analysis of influence of separate macroeconomic parameters is carried out. Among them: GDP, gross value added, gross capital formation and export balance, ensuring household income growth and employment. According to the design concept, they are key factors in social development. According to the analysis results the number of people employed in the economy by $72-73 \%$ correlates with GDP and GVA growth, but this relationship turned out to be negative. One

\footnotetext{
${ }^{1}$ Black Sea Research Institute of Economics and Innovation; Applicant; ORCID ID: https://orcid.org/00000001-8919-2114; e-mail management@nuos.edu.ua; Scientific Adviser - I. O. Irtyshcheva, Doct. Ec. Sc., Professor.
} 
of the reasons for the negative correlation may be the growth of labour productivity due to the introduction of innovative technologies. Practical meaning. Employment growth is also negatively affected by the processes of optimizing the number of employees in enterprises due to certain structural changes, including reduction of the share of industry in the structure of GDP, reduction of employees in the budget sphere and increase of the services sector, which does not require such a large number of employees. In the future, the extrapolation of these trends threatens to further deteriorate the labour market. Prospects for further research. Using correlation-regression analysis, close correlations have been established between household incomes and the growth of gross value added in the economy, the increase in the export balance and the gross accumulation of capital. Using correlation-regression analysis, close correlations have been established between household incomes and the growth of gross value added in the economy, the increase in the export balance and the gross accumulation of capital. This indicates the priority of developing economic activities with a high level of value added, increasing exports and capital investment as imperative factors in reducing poverty in the long run.

Keywords: national economy, design management, model of strategic management, correlationregression analysis, strategic concept.

JEL Classification: I00; I11; I18; I19.

Number of references: 10; number of tables: 2; number of figures: 2; number of formulas: $\mathbf{0 .}$

\section{Стратегічний концепт розвитку національної економіки у фокусі дизайн-менеджменту}

\section{Наталя Олександрівна Прокопенко ${ }^{1}$}

Стаття надійшла: 11.02 .2019 Статmя прийнята: 15.03 .2019
Prokopenko N. O. Strategic concept of national economy development in the focus of design management. Економічні горизонти. 2020. № 1(12). C. 50-62. DOI: $10.31499 / 2616-5236.1(12) \cdot 2020.224549$

Анотація. Метою статті є обгрунтування стратегічного концепту розвитку національної економіки у фокусі дизайн-менеджменту. Методологія. У досліджені застосовані загальнонаукові методи, зокрема теоретичного узагальнення - для визначення теоретичних основ і тенденцій змісту й складових дизайн-менеджменту; системного економічного аналізу - для обгрунтування моделі стратегічного управління економічними трансформаціями у контексті дизайнменеджменту; статистичного аналізу, а саме кореляційно-регресійного аналізу - для дослідження залежності між макроекономічними показниками та показниками соціальної сфери. Результати. Доведено, що поточна економічна модель національної економіки є непридатною для реалізації цілей сталого розвитку, забезпечення конкурентоспроможності держави у глобальному оточенні та достойного рівня життя громадян у довгостроковій перспективі. Намагання удосконалити (реформувати) окремі параметри та складові застарілої моделі можуть призвести до втрати часу та ресурсів, що зумовить подальше відставання України від розвинутих країн світу. Вирішення проблеми забезпечення достойного рівня життя громадян та розвитку людського потенціалу потребує комплексного реінжинірингу структури та процесів функціонування соціально-економічної системи на засадах дизайн-менеджменту. Дослідження особливостей дизайн-менеджменту, який являє собою інноваційну концепцію мислення, дозволило сформулювати власний підхід до визначення стратегічного управлінням національною економікою, під яким запропоновано розуміти процес проектування соціально-економічної моделі розвитку,

1 Причорноморський науково-дослідний інститут економіки та інновацій; здобувач; ідентифікатор ORCID: https://orcid.org/0000-0001-8919-2114; e-mail: management@nuоs.edu.иа; науковий керівник I. О. Іртищева, д. е. н., професор. 
параметри функціонування якої гарантуватимуть достойний рівень задоволення потреб населення в довгостроковій перспективі, вибір системи оптимальних стратегій та механізмів їх реалізації з урахуванням факторів забезпечення державної безпеки та збереження природного середовища. Обгрунтовано відповідну модель стратегічного управління економічними перетвореннями, окреслено основні напрямки та пріоритети економічної політики (галузевої, фіскальної, тарифної, митної та політики у сфері держзакупівель), спрямованої на реалізацію якісних структурних перетворень для забезпечення економічного зростання національної економіки у стратегічній перспективі. Проведено кореляційно-регресійний аналіз впливу окремих макроекономічних параметрів, серед яких ВВП, валова додана вартість, валове нагромадження капіталу та експортне сальдо на забезпечення росту доходів домогосподарств і рівень зайнятості населення, що відповідно до концепції дизайну виступають у якості ключових чинників соціального розвитку. Практичне значення. Результати аналізу показали, що чисельність зайнятих в економіці осіб на 72-73\% корелює з ростом ВВП та ВДВ, проте такий зв'язок виявився від'ємним. Однією з причин від'ємної кореляції може бути зростання продуктивності праці внаслідок впровадження інноваційних технологій. Негативно на ріст зайнятості впливають також процеси оптимізації чисельності працівників на підприємствах через певні структурні зміни, зокрема скорочення питомої ваги промисловості в структурі ВВП, скорочення працівників у бюджетній сфері та збільшення сектору послуг, що не потребує такої кількості найманих працівників. Екстраполяція вказаних тенденцій в майбутньому загрожує подальшому погіршенню стану ринку праці. Перспективи подальших досліджень. 3 використанням кореляційнорегресійного аналізу встановлено тісні кореляційні зв'язки між доходами домогосподарств та зростанням валової доданої вартості в економіці, підвищенням експортного сальдо та валовим нагромадженням капіталу, що засвідчує пріоритетність розвитку видів економічної діяльності 3 високим рівнем доданої, нарощенням експорту та капітальних інвестицій як імперативних чинників скорочення бідності населення у довгостроковій перспективі.

Ключові слова: національна економіка, дизайн-менеджмент, модель стратегічного управління, кореляційно-регресійний аналіз, стратегічна концепція.

Кількість джерел: 10; кількість таблиць: 2; кількість рисунків: 2; кількість формул: 0.

\section{Introduction.}

Today, the words "design" and "innovation" become synonymous, because the final design determines the essence, sequence and balance of processes for creating a new product (project, service), which are focused on the maximum satisfaction of certain needs or their formation. Analytical thinking, based on the processing of existing information, defined procedures, rules and methods of decision-making that underlie the management of traditional systems in a rapidly changing market become irrelevant and do not bring the expected results. For innovations and qualitative structural transformations of the economy at all levels, a fundamentally new type of thinking becomes necessary, which is based on the obligatory creative component, namely the ability to synthesize and create new ones.
It is obvious that a wide range of problems that characterize the current state of the national economy and society cannot be solved by traditional administrative means of using the existing state regulation elements and levers. To ensure comprehensive modernization of the national economy and society in the direction of accelerated transition to the sustainable development model, which is recognized as the basic concept of Ukraine's development until 2030, a comprehensive strategic approach based on the concept of management design is needed.

\section{Literature review.}

Given the breadth, complexity, multivector and multifaceted problems of the national economy in the strategic perspective, many theoretical and practical studies are devoted to these issues, methodological con- 
cepts, approaches and models are developed. In particular, various aspects of the national economy strategic development are covered in the works of N. Kshytof (2015), V. Halasiuk (2019), V. Paymanova (2014), M. Aubry and M. Brunet (2014), M. Maslow (1954), I. Irtyshcheva and I. Kramarenko (2014) and many other scientists.

Despite significant scientific achievements, the issues of strategic development of the national economy in the context of management design in the Ukrainian works are considered only superficially. The successful design management implementation in the operation of governments of certain countries, global corporations and its impact on the effectiveness of their operation arouse scientific and practical interest in the prospects of its application in the national economy.

\section{Methodology.}

The theoretical and methodological basis of the study are the scientific works in the field of national economic development in the focus of design management. To achieve the purpose of the work, the following research methods were used: theoretical generalization - to determine the theoretical foundations and trends of content and components of design management; system economic analysis - to substantiate the model of strategic economic transformations management in the context of design management; statistical analysis, namely correlation-regression analysis - to study the relationship between macroeconomic indicators and social indicators.

\section{Research objectives.}

The purpose of the article is to substantiate the strategic concept of national economy development in the focus of design management.

\section{Results and discussions.}

The current state of the national economy is the result of an irrational development model based on inefficient use of available resources, bureaucratic and corrupt mechanisms of administration, development of monopolies and the shadow economy, as well as the lack of effective strategies for socioeconomic development. It is characterized by a number of systemic economic and social crises, deteriorating environmental conditions and significant loss of economic potential. In particular, over the last thirty years, the rate of decline in real GDP compared to 1991 was more than $65 \%$. This has shifted the country's GDP per capita from 10th to last in Eastern Europe. And the population decreased by almost $20 \%$.

We agree with the opinion of N. Kshytof "The objective and subjective preconditions for making a state decision on the formation of a certain national economic model and its transformation are the growth of crises, exacerbation of contradictions in all areas, falling living standards and increasing public and external debt. This, in fact, is the basis for reviewing the existing model and deciding on the need to adjust or change it. According to the analysis, Ukraine is currently in such a situation" (Kshytof, 2015). The author argues that for countries that are currently characterized by structural crises, disparities in economic development and a significant decline in the citizens' lives as a result of non-compliance with the global market competitive conditions, the most optimal way is not to adjust or improve the existing model of socio-economic development, but to radically change it. At the same time, it is important for the nation to have a clear awareness of its role and place in the world, fundamental values and ideals, as well as a real assessment of the available potential.

Definitely, Ukraine's financial situation, which is characterized by high levels of external and domestic debt, requires tough measures to optimize expenditures and balance the budget to achieve macro-financial stability. This will allow to repay your obligations to external and internal creditors in a timely manner and thus avoid the threat of default.

According to the research, the focus of the economy solely on reducing government 
spending and budget expenditures while increasing the fiscal burden, as required by the IMF, cannot lead to economic development and creates preconditions for aggravation of social conflicts, degradation of social institutions, lower living standards, reduction of the domestic market and a corresponding decrease in business activity of domestic business. Solving the problems of economic development and stabilization of the financial situation of the national economy requires the development of an effective economic model that will ensure the most effective use of strategic potential, stimulate investment activity and increase gross income.

Additional obligations to achieve certain social, economic and environmental parameters of the national economy are defined in international treaties and memoranda signed by Ukraine. The most important for the strategic development and modernization of the state are the requirements set out in the EUUkraine Association Agreement, as their implementation is an important prerequisite for full integration into the European Union. To date, Ukraine has developed a set of strategic documents and reforms designed to implement them. In particular, an important step is a clear definition of the Ukrainian strategic course as well as a strategic vision of national economy development that corresponds to the development model of successful countries, in particular the EU.

According to the "Sustainable Development Strategy for Ukraine by 2030", the new worldview paradigm on which the Strategy is based is a political and practical model of such development worldwide, which meets the needs of the current generation without compromising the ability of future generations to meet their own needs (The Verkhovna Rada of Ukraine, 2019). This model is focused on achieving the optimal balance between the three components of development economic, social and environmental.

The effectiveness of the strategy implementation will be determined primarily by the level of achievement of the sustainable development goals approved in the Sustainable Development Goals of Ukraine until 2030. These goals cover 17 areas: overcoming poverty, overcoming hunger, agricultural development, good health and well-being, quality education, gender equality, clean water and sanitation, affordable and clean energy, decent work and economic growth, industry, innovation and infrastructure, reducing inequality, sustainable development of cities and communities, responsible consumption and production, climate change mitigation, conservation of marine resources, protection and restoration of land ecosystems, peace, justice and strong institutions, partnership for sustainable development.

In our opinion, the effectiveness of this concept implementation and the achievement of strategic goals of Ukraine require reengineering of the current management model at all levels. In addition, it requires the comprehensive project development for the state development, taking into account the potential opportunities arising from the development of the world economic system. For this purpose it is advisable to turn to methodological approaches, the effectiveness of which has been proven in practice by the best world experience in this field. In particular, this approach can be considered design management.

We agree with the opinion of V. Halasiuk that "neoliberal economic policy, which many international experts continue to call successful, instead of modernization, causes economic stagnation in countries that are at a lower level of technological development and quality of production structure than the advanced countries of the world. It is necessary to get rid of the market fundamentalism dogmas and take as a basis that the neglect of conscious national economy management is no less reckless than the abandonment of regular management in business. This is because at the macro level the economic system is "designed" through the mechanisms of economic policy as well as the 
activities of individual enterprises through corporate governance" (Halasiuk, 2019).

Significant "gaps" between the strategic goals of Ukraine's development and the current situation require a temporary abandonment of the neoliberalism principles and the growing role of the state in regulating economic processes in order to establish an effective and balanced structural-sectoral, legal and administrative-territorial model of development, which corresponds to the real strategic potential of the country, taking into account the key trends, conditions and drivers of economic growth. To do this, the transformation processes taking place in socioeconomic systems at all levels must be managed in some way, have a single strategic vector and certain imperatives.

The application of methodological approaches of design management in the formation of an effective model of the national economy transformation requires the identification of key features of this approach and points of contact with the classical theory of strategic management, which is used in public administration for further integration.

The term "design" has been used in everyday life for many decades and occupies an important place in people's minds. Most often, when using this word, works of art, geniuses, unique in their form and appearance of the phenomenon come to mind. By its nature, design means creative activity that aims at structural and functional changes to transform the design object into a single whole that is in harmony with the environment (Paymanova, 2014).

Design is recognized as one of the drivers of innovative development and ensuring the competitiveness of EU countries and is included in the innovative development program of the European Union. The benefits of design as a modern business philosophy are set out in the EU report "Design as a driver of user-centred innovation". According to the report, companies that use design management achieve much greater success than com- panies with a traditional approach to management. For example:

- companies that used design in the formation of strategic goals, produced new products 5 times faster than competitors;

- the analysis of small and mediumsized enterprises in Ireland showed that $75 \%$ of those who use design are 3 times faster to commercialize innovations;

- design increases profitability by an average of $17 \%$, provided it is used effectively at all stages of product development;

- The design is less capital intensive and allows to get results faster (on average in 2 years) and has a shorter purchase period than other factors of innovation (Council of the European Union, 2009).

Studies show that due to the peculiarities of the design concept, the adaptation of design principles to the peculiarities of public administration in scientific works is considered only in fragments and is used mainly in organizing political parties and partly in forming government programs. In this regard, there is a need to determine the essence of design management in the management of the national economy, its functions, features and directions of adaptation to the realities.

Researchers M. Aubry and M. Brunet, studying the possibilities of implementing design management in public administration processes, came to the conclusion that the existing organizational (bureaucratic) structures used in government and local government are not able to effectively implement design projects due to lack of coherence, standards and decision-making procedures, insufficiently defined responsibilities (Aubry and Brunet, 2014).

Scientists emphasize that the introduction of management design in government agencies involves primarily a comprehensive management structures reengineering and the formation of an appropriate management culture based on competence and innovation.

In a broad sense, design management involves the creation of the most optimal (rel- 
evant) product model that will meet the requirements of the target audience and purposeful design of business processes to create this product, taking into account the available potential. The essence of the design approach to management is revealed in the features of design thinking and their implementation in practice, including:

1. Focus on the consumer, on his real needs. Empathy and identification of key consumer needs is the basis for project development (model, prototype) of a product or service;

2. The focus is not from the past to the future, but from the future to the present, which distinguishes this approach among most management practices, including strategic management. Design management is focused on the end result (i.e. the finished product), which will meet the target consumer characteristics and not the individual goals that are inherent in the strategic type of thinking;

3. Simplicity, versatility and affordability. Design management is focused on finding the simplest and most cost-effective ways to implement the project at all stages. The final product should also not contain redundant functions.

Transferring the principles of design management to the national economy management is not an easy task given the complexity and scale of the national economy, functions, management methods, the multiplicity of goals, objectives and factors of influence. At the same time, it is possible to identify key benchmarks that will optimize the system of strategic management on the basis of design management.

A clear definition of the key needs of the conventional consumer, namely the population of Ukraine. That is, the leading function of the prototype model of strategic development of the national economy is its ability to meet the sustainable and long-term needs of more than $90 \%$ of the population. In our opinion, the state exists for the people who live in it, so the basis of the strategic model of national economy development is to meet the general needs of the population. The higher the development level of a country, the better its citizens' needs are met (United $\mathrm{Na}$ tions Ukraine, 2017).

To determine the basic needs, A. Maslow's theory of motivation can be used (Maslow, 1954). The theory explains the essence, structure and hierarchy of human needs. According to it, human needs are in a certain hierarchy, and work on the principle of moving to the next level while meeting the previous one. The application of A. Maslow's theory will allow to determine the basic needs of a conditional citizen, their hierarchy and to develop an appropriate strategic project. In Figure 1. the hierarchy of needs of A. Maslow and the corresponding indicators which can be used for model formation are given. Certainly, these indicators are conditional and can be supplemented or expanded by other groups of quantitative and qualitative indicators.

Thus, the strategic national economy management in the focus of design management can be understood as the process of designing a socio-economic model of development. The parameters of its operation will guarantee a decent level of the needs satisfaction of the population in the long run, the choice of an optimal strategies and mechanisms system for their implementation, taking into account the factors of national security and environmental protection.

Given the design technology peculiarities, the strategic process of forming an economic development model (at any level) and the choice of transformation strategies that will accompany its implementation, can be reflected in the scheme (Figure 2).

According to experts, a positive scenario of national economy transformation involves the creation of a national economy, the main qualitative differences of which will be the formation of such characteristics as high technology and social responsibility. Such an 
economy will generate high demand for high- financial resources and transform them on an ly qualified specialists, accumulate significant innovative basis into long-term investments.

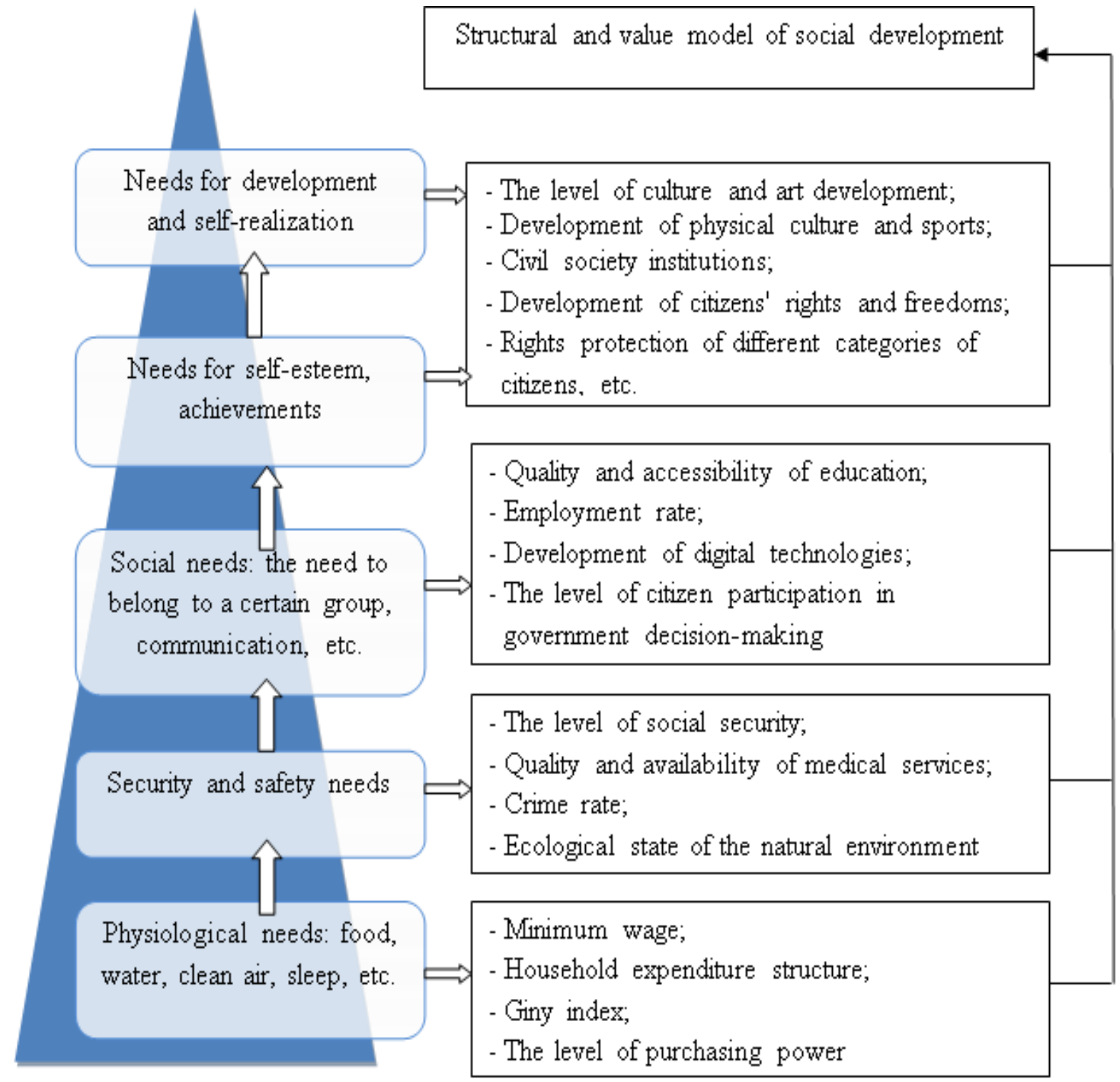

\section{Fig. 1. Hierarchy of population needs and their satisfaction indicators in the context of design management at the level of national socio-economic systems}

Source: suggested by the author.

The economic conditions of the model functioning determine the main parameters of the economy, under which the achievement of the goals set in the structural-value model of economic development should be ensured. In terms of meeting the population needs, the economic development priority is the balanced model formation of economic development that can provide a high level of employment, income and a sufficient level of food security. One of the key final indicators that directly or indirectly contribute to ensuring the effective implementation of the structural and value model of social development is the employment and income level. In this context, a strategically important consideration of the economic transformations management is the choice of priorities for economic growth, namely the sectoral analysis of promising economic activities that are designed to ensure the growth of employment and income.

According to experts, a positive scenario of national economy transformation involves the creation of a national economy, the main qualitative differences of which will be the formation of such characteristics as high technology and social responsibility. Such an 
economy will generate high demand for high- financial resources and transform them on an ly qualified specialists, accumulate significant innovative basis into long-term investments.

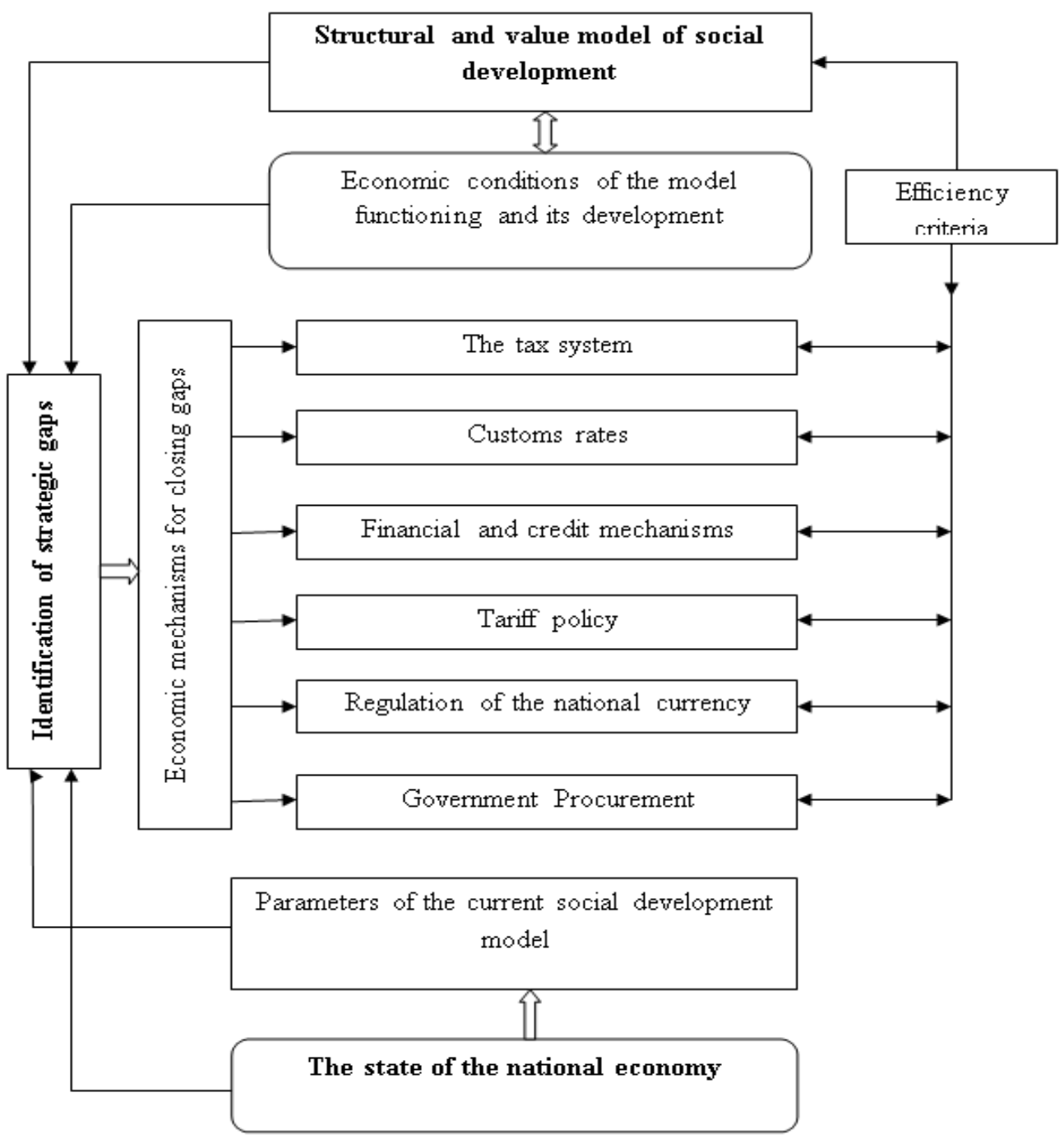

Fig. 2. Model of strategic management of economic transformations in the context of

Source: author's development. design management

The economic conditions of the model functioning determine the main parameters of the economy, under which the achievement of the goals set in the structural-value model of economic development should be ensured. In terms of meeting the population needs, the economic development priority is the balanced model formation of economic development that can provide a high level of employment, income and a sufficient level of food security. One of the key final indicators that directly or indirectly contribute to ensuring the effective implementation of the structural and value model of social development is the employment and income level. In this context, a strategically important consideration of the economic transformations management is the choice of priorities for economic growth, namely the sectoral analysis of promising economic activities that are designed to ensure the growth of employment and income.

Hypothetically, it is assumed that the growth of incomes and employment is stimulated by the level of production (operational) activity in the economy. This can be indirectly determined by the gross accumulation of fixed capital, the level of resource processing and the complexity of production and service processes, which affects the increase in gross 
Prokopenko N. O. Strategic concept of national economy development in the focus of design management

value added and the export balance, which characterizes the economy competitiveness in the global market.

To determine the impact of key macroe- conomic parameters that affect employment and household income, a correlation analysis was conducted for the period 2008-2018. $\mathrm{Ta}$ ble 1 shows the initial data for analysis.

Table 1. Initial data for correlation-regression analysis of the impact on income and employment in Ukraine

\begin{tabular}{|c|c|c|c|c|c|c|}
\hline Period & $\begin{array}{c}\text { Employed } \\
\text { population, } \\
\text { thousand } \\
\text { people, } \mathbf{Y}_{\mathbf{1}}\end{array}$ & $\begin{array}{c}\text { Total house- } \\
\text { hold income, } \\
\text { UAH per } \\
\text { household per } \\
\text { month, } \mathbf{Y}_{\mathbf{2}}\end{array}$ & $\begin{array}{c}\text { GDP, } \\
\text { UAH mil- } \\
\text { lion, } \mathbf{X}_{\mathbf{1}}\end{array}$ & $\begin{array}{c}\text { Gross val- } \\
\text { ue added, } \\
\text { UAH mil- } \\
\text { lion, } \mathbf{X}_{\mathbf{2}}\end{array}$ & $\begin{array}{c}\text { Balance of ex- } \\
\text { ports and imports } \\
\text { of goods and ser- } \\
\text { vices, UAH mil- } \\
\text { lion, } \mathbf{X}_{\mathbf{3}}\end{array}$ & $\begin{array}{c}\text { Gross fixed } \\
\text { capital for- } \\
\text { mation, } \\
\text { UAH mil- } \\
\text { lion, } \mathbf{X}_{\mathbf{4}}\end{array}$ \\
\hline 2008 & $19,251.7$ & $2,892.8$ & 990,819 & 866,939 & $-84,734$ & 206,900 \\
\hline 2009 & $18,365.0$ & $3,015.3$ & 947,042 & 830,178 & 28,591 & 112,872 \\
\hline 2010 & $17,451.5$ & $3,369.8$ & $1,079,346$ & 954,472 & $-43,533$ & 225,296 \\
\hline 2011 & $17,520.8$ & $3,708.2$ & $1,299,991$ & $1,122,558$ & $-85,918$ & 291,678 \\
\hline 2012 & $17,728.6$ & $4,031.9$ & $1,404,669$ & $1,213,069$ & $-121,525$ & 305,031 \\
\hline 2013 & $17,889.4$ & $4,331.0$ & $1,465,198$ & $1,283,812$ & $-135,329$ & 270,895 \\
\hline 2014 & $17,188.1$ & $4,470.9$ & $1,586,915$ & $1,382,719$ & $-55,635$ & 212,591 \\
\hline 2015 & $15,742.0$ & $5,122.0$ & $1,988,544$ & $1,689,387$ & $-51,926$ & 316,841 \\
\hline 2016 & $15,626.1$ & $6,095.0$ & $2,385,367$ & $2,023,228$ & $-165,162$ & 518,201 \\
\hline 2017 & $15,495.9$ & $8,013.1$ & $2,983,882$ & $2,519,561$ & $-229,438$ & 595,194 \\
\hline 2018 & $15,718.6$ & $9,720.2$ & $3,560,596$ & $3,018,190$ & $-310,497$ & 661,801 \\
\hline
\end{tabular}

Source: data from the State Statistics Service of Ukraine

The data in the Table 1 shows that during the study period the number of people employed in the economy of Ukraine decreased by $18 \%$. The negative balance of exports also increased significantly. This shows the negative trends in reducing both internal and external competitiveness of Ukraine. All other macroeconomic indicators for the stud- ied period increased more than 2 times. This is partly due to rapid inflation in the economy during the study period.

The correlation-regression analysis revealed linear dependences between social factors and macroeconomic indicators, as shown in Table 2.

Table 2. Correlation-regression analysis of the impact of certain macroeconomic parameters on social status indicators in Ukraine

\begin{tabular}{|c|c|c|}
\hline Indicators & $\begin{array}{l}\text { Employed population, thou- } \\
\text { sand people, } Y_{1}\end{array}$ & $\begin{array}{l}\text { Total household income, UAH } \\
\text { per household per month, } \mathrm{Y}_{2}\end{array}$ \\
\hline 1. GDP, UAH million, $\mathrm{X}_{1}$ & $Y_{1}=19,072-0.006 X_{1}$ & $Y_{2}=474.9+0.002 X_{1}$ \\
\hline Coefficient of determination $\left(\mathrm{R}^{2}\right)$ & 0.73 & 0.99 \\
\hline $\begin{array}{l}\text { 2. Gross value added, UAH } \\
\text { million, } \mathrm{X}_{2}\end{array}$ & $Y_{1}=19,415.42-0.002 X_{2}$ & $Y_{2}=332.6+0.003 X_{2}$ \\
\hline Coefficient of determination $\left(\mathrm{R}^{2}\right)$ & 0.72 & 0.99 \\
\hline $\begin{array}{l}\text { 3. Balance of exports and } \\
\text { imports of goods and services, } \\
\text { UAH million, } X_{3}\end{array}$ & $\begin{array}{l}\text { There is no functional } \\
\text { connection }\end{array}$ & $Y_{2}=2,641.4-0.02 X_{3}$ \\
\hline Coefficient of determination $\left(\mathrm{R}^{2}\right)$ & 0.35 & 0.80 \\
\hline $\begin{array}{l}\text { 4. Gross fixed capital } \\
\text { formation, UAH million, } \mathrm{X}_{4}\end{array}$ & $Y_{1}=19,072-0.006 X_{2}$ & $Y_{2}=1,019.9-0.12 X_{4}$ \\
\hline Coefficient of determination $\left(\mathrm{R}^{2}\right)$ & 0.66 & 0.90 \\
\hline
\end{tabular}

Source: calculated by the author 
The verification of the significance of the connection was carried out according to Fisher's test and with a probability of $0.95 \%$ showed that all models are statistically significant.

The obtained regression models allow us to conclude that there is a direct relationship between the basic parameters of the economy and the social status of the population. This is determined by the indicators of total household income and the number of employees. In particular:

1. The number of people employed in the economy by $72-73 \%$ correlates with GDP and GVA growth, but this relationship turned out to be negative. One of the reasons for the negative correlation may be the growth of labor productivity due to the introduction of innovative technologies. This is also indirectly evidenced by the negative correlation between the number of employees and the gross accumulation of fixed capital. Employment growth is also negatively affected by the processes of optimizing the number of employees in enterprises due to certain structural changes, including reduction of the share of industry in the structure of GDP, reduction of employees in the budget sphere and increase of the services sector, which does not require such a large number of employees. In the future, the extrapolation of these trends threatens to further deteriorate the labor market. Therefore, one of the tasks at the current stage is to stimulate the development of the economy sectors that are potentially able to create new jobs, purposeful formation of state policy in employment and education to ensure effective labor market and balance, to stimulate small business and self-employment.

2. The conducted regression analysis showed a high dependence of gross household income on the studied parameters of the economy. In particular, in the absence of other factors, GDP growth of UAH 1 million causes an increase in average monthly household income by UAH 0.002, and an increase in gross value added in the economy - by
UAH 0.003. This indicates that one of the factors reducing poverty in the long run is the development of economic activities with a high level of value added.

As the balance of exports in Ukraine during the study period was mostly negative, it also had a negative impact on the level of citizens' income. In particular, the analysis showed that the excess of exports over imports by UAH 1 million allows to increase the level of citizens' incomes by UAH 0.02 within the country. Gross capital accumulation in the economy, i.e. capital investment, also has a positive effect on income growth. The growth of this indicator by UAH 1 million stimulates the growth of citizens' incomes by UAH 0.12 .

Thus, we can conclude that the construction of an effective and balanced economy structure and the development of appropriate social policies are imperative prerequisites for achieving the goals of our country's sustainable development. The authors of the balanced development doctrine "Ukraine 2030" argue that "given Ukraine's potential strengths, it is important to identify the drivers of the future innovation leap - economic sectors and economic activities that could create high-quality products and services with a high share of value added on an innovative basis and would be in demand in international markets" (Zhylinska et al., 2017).

\section{Conclusions.}

It is proved that the current economic model of the national economy is unsuitable for achieving the goals of sustainable development, ensuring the competitiveness of the state in the global environment and a decent standard of living in the long run. Attempts to improve (reform) certain parameters and components of the outdated model may lead to a loss of time and resources, which will cause Ukraine to further lag behind the developed countries of the world. Solving the problem of ensuring a decent living standard for citizens and the human potential development requires a comprehensive reengineering of the 
structure and processes of the socio-economic system based on design management.

Design management is an innovative concept of thinking. The study of its features allowed to formulate our own approach to determining the strategic management of the national economy. Under this approach, it is proposed to understand the process of designing a socio-economic model of development. The parameters of its operation will guarantee a decent satisfaction level of the population needs in the long run, the choice of a system of optimal strategies and mechanisms for their implementation, taking into account the factors of national security and environmental protection. The corresponding model of strategic management of economic transformations is substantiated. The main directions and priorities of economic policy (sectoral, fiscal, tariff, customs and public procurement policy) aimed at the implementation of qualitative structural transformations to ensure economic growth of the national economy in the strategic perspective are given.

The correlation-regression analysis of influence of separate macroeconomic parameters is carried out. Among them: GDP, gross value added, gross capital formation and export balance, ensuring household income growth and employment. According to the design concept, they are key factors in social development. According to the analysis results the number of people employed in the economy by $72-73 \%$ correlates with GDP and GVA growth, but this relationship turned out to be negative. One of the reasons for the negative correlation may be the growth of labor productivity due to the introduction of innovative technologies. Employment growth is also negatively affected by the processes of optimizing the number of employees in enterprises due to certain structural changes, including reduction of the share of industry in the structure of GDP, reduction of employees in the budget sphere and increase of the services sector, which does not require such a large number of employees. In the future, the extrapolation of these trends threatens to further deteriorate the labor market.

Using correlation-regression analysis, close correlations have been established between household incomes and the growth of gross value added in the economy, the increase in the export balance and the gross accumulation of capital. This indicates the priority of developing economic activities with a high level of value added, increasing exports and capital investment as imperative factors in reducing poverty in the long run.

\section{References}

Aubry, M. and Brunet, M. (2014), “Organizational design in public administration: typology of project management offices”, Project Management Institute Research and Education Conference, available at: https://www.pmi.org/learning/library/organizational-design-public-administration-8941 (Accessed 21 January 2020).

Council of the European Union (2009), “Design as a driver of user-centred innovation”, available at: https://register.consilium.europa.eu/doc/srv?l=EN\&f=ST\%208706\%202009\%20INIT (Accessed 21 January 2020).

Halasiuk, V. V. (2019), "State regulation of national economy transformation”, Thesis for a Doctoral Degree of Economic Sciences, Economics and management of national economy, National Academy of Management, Kyiv.

Irtyshcheva, I. O. and Kramarenko, I. S. (2014), “Investment attractiveness of the economy: inter-regional asymmetries", Regional economy, no. 2(72), pp. 84-95.

Kshytof, N. S. (2015), "Transformation of the development economic model as a scientific and practical problem of public administration", Public administration: theory and practice, no. 1, pp. 4-11.

Maslow, A. H. (1954), Motivation and Personality, Harpaer\&Row, New York, USA, 353 p.

Paymanova, V. A. (2014), “Institutional design of the capital market as an economic category", Business Inform, no. 7, pp. 23-27. 
The Verkhovna Rada of Ukraine (2019), The Law of Ukraine "Sustainable Development Strategy for Ukraine by 2030”, available at: https://zakon.rada.gov.ua/laws/show/722/2019\#Text (Accessed 21 January 2020).

United Nations Ukraine (2017), “Sustainable Development Goals: Ukraine. National Report 2017”, available at: http://www.un.org.ua/images/SDGs NationalReportUA Web 1.pdf (Accessed 21 January 2020).

Zhylinska, O. (ed.), Melnychuk, O. (ed.), Antoniuk, L., Humenna, O., Radchuk, A., Stoliarchuk, Ya., Taruta, S., Kharlamova, H., Chala, N. and Shnyrkov O. (2017), Ukraina 2030: Doktryna zbalansovanoho rozvytku [Ukraine 2030: The doctrine of balanced development] Kalvariia, Lviv, Ukraine, 164 p., available at: http://econom.chnu.edu.ua/wp-content/uploads/2018/03/E-Book-Doctrine-2030.pdf (Accessed 21 January 2020).

Цей твір ліцензовано на умовах Ліцензії Creative Commons «/з Зазначенням Авторства - Некомерційна 4.0 Міжнародна» (CC BY-NC 4.0). This is an open access journal and all published articles are licensed under a Creative Commons "Attribution-NonCommercial 4.0 International" (CC BY-NC 4.0). 